\title{
ANALISIS TINGKAT USAHATANI KAKAO (Theobroma cacaon) STUDI KASUS DI DESA LATU KECAMATAN AMALATU KABUPATEN SERAM BAGIAN BARAT
}

\author{
Raihana Kaplale \\ Staf Pengajar Jurusan Budidaya Pertanian FAPERTA-UNPATI, $\boldsymbol{e}$-mail:
}

\begin{abstract}
ABSTRAK
Desa Latu merupakan salah satu daerah penghasil kakao di Kecamatan Amalatu Kabupaten Seram Bagian Barat sebagai salah satu sumber pendapatan petani. Penelitian ini bertujuan untuk mengetahui tingkat pendapatan petani kakao, faktor-faktor yang mempengaruhi pendapatan usahatani kakao, dan kelayakan usahatani kakao. Sampel ditentukan dengan metode acak sederhana (simple random sampling). Jumlah responden terpilih sebanyak 32 petani (25\%) dari 128 Kepala Keluarga (KK) yang mengusahakan usahatani kakao.

Hasil penelitian menunjukkan bahwa rata-rata tingkat pendapatan usahatani kakao adalah $R p$ 6,2 juta/ha/thn. Berdasarkan hasil analisis regeresi linier berganda, factor-faktor utama penentu tingkat pendapatan usahatani kakao yaitu luas lahan, biaya produksi, produksi dan harga jual. Usahatani kakao layak karena menguntungkan berdasarkan nilai BCR 3,89.
\end{abstract}

\section{Kata Kunci: Theobroma cacao, Amalatu, Seram bagian Barat}

\section{PENDAHULUAN}

\subsection{Latar Belakang}

Pembangunan nasional dewasa ini diprioritaskan pada bidang perekonomian sehingga pemerintah selalu berusaha untuk menerapkan kebijaksanaan dalam peningkatan hasil produksi pertanian. Apalagi negara kita terkenal dengan negara agraris yang mempunyai areal pertanian yang mempunyai areal pertanian yang cukup luas, dengan sumber daya alam yang sangat perlu digali dan dimanfaatkan untuk pemenuhan kebutuhan manusia. Sasaran utama pembangunan pertanian dewasa ini adalah peningkatan produksi pertanian dan pendapatan petani. Pembangunan pertanian yang diusahakan pada berbagai bidang cabang usahatani dari sektor pertanian, ditujukan agar petani dapat berhasil dalam usahanya dengan memperoleh pendapatan yang lebih tinggi.

Salah satu subsektor pertanian yang dijadikan titik perhatian untuk terus dikembangkan adalah subsektor perkebunan. Kakao (Theobroma Cacao, L) adalah salah satu komoditas perkebunan yang memiliki peranan penting dalam pembangunan, karena dilihat dari peran ekonomi kedepan dan kebelakangnya cukup besar.
Desa Latu adalah merupakan salah satu desa yang terletak di Pulau Seram, tepatnya di Kabupaten Seram Bagian Barat, Kecamatan Ama Latu. Desa Latu mayoritas mata pencaharian penduduk 70 persen adalah sebagai petani. Usahatani kakao yang berada di Desa Latu diusahakan dalam bentuk perkebunan rakyat karena usaha tersebut dikelola oleh petani sendiri dengan tujuan untuk memenuhi kebutuhan keluarga.

Kegiatan usahatani kakao yang dilakukan tidak didasari oleh prinsip ekonomi, yaitu manajemen usaha. Petani tidak pernah melakukan proses pencatatan dan perhitungan dari setiap biaya yang dikeluarkan selama proses produksi, sehingga petani tidak mengetahui untung atau rugi dari usahatani kakao yang dijalankan. Oleh karena itu diperlukan suatu penelitian terhadap usahatani kakao yang dilakukan oleh petani untuk mengetahui masalahmasalah yang dihadapi guna peningkatan produksi dan perbaikan tingkat pendapatan petani yang mempengaruhi tingkat kesejahteraan terhadap keluarga petani tersebut. 


\subsection{Tujuan Penelitian}

Adapun tujuan dari penelitian ini adalah untuk mengetahui :

1. Tingkat pendapatan yang diterima oleh petani dari usahatani kakao.

2. Besarnya kontribusi pendapatan usahatani kakao terhadap pendapatan keluarga petani.

3. Faktor-faktor apa saja yang mempengaruhi tingkat pendapatan keluarga petani kakao.

4. Kelayakan usahatani kakao di Desa Latu Kecamatan Ama Latu Kabupaten Seram Bagian Barat

\subsection{Manfaat Penelitian}

Dari hasil penelitian tersebut diharapkan dapat memberi manfaat sebagai berikut:

1. Sebagai sumbangan pemikiran bagi pemerintah daerah khususnya dalam rangka pembinaan terhadap petani kakao dalam upaya peningkatan hasil produksi dan tingkat pendapatan petani.

2. Untuk menambah pengalaman dan pengetahuan penulis tentang masalah pertanian khususnya sektor tanaman coklat

3. Sebagai bahan referensi dan perbandingan bagi peneliti berikutnya yang akan melakukan pengkajian masalah yang relevan.

\section{METODO PENELITIAN}

\subsection{Waktu dan Lokasi Penelitian}

Penelitian ini dilaksanakan di Desa Latu Kecamatan Amalatu Kabupaten Seram Bagian Barat. Penelitian ini berlangsung pada bulan Desember 2010 sampai bulan Januari 2011.

\subsection{Metode Pengambilan Sampel}

Metode pengambilan sampel yang digunakan dalam penelitian ini adalah secara acak sederhana (simple random sampling) sebesar 25 persen dari 128 kepala keluarga (KK) yang mengusahakan usahatani kakao, dimana setiap kepala keluarga petani kakao mempunyai peluang yang sama untuk dipilih menjadi responden (Singarimbun dan Effendi, 1982).

\subsection{Metode Pengumpulan Data}

Data yang digunakan dalam penelitian ini adalah meliputi data primer dan data sekunder. Data primer adalah data yang diperoleh dari pengamatan langsung melalui teknik wawancara langsung dengan menggunakan daftar pertanyaan yang telah disiapkan, sedangkan data sekunder adalah dari beberapa pustaka serta informasi dari instansi terkait.

\subsection{Kerangka Analisis}

Analisis yang digunakan untuk menjawab masalah pertama menyangkut besarnya tingkat pendapatan petani kakao adalah:

Untuk menghitung penerimaan digunakan formula (Soekartawi, 1995):

$$
T R i=Y i . P y i
$$

Dimana :

TRi : Total penerimaan dari hasil usahatani kakao

Yi : Produksi yang diperoleh dari hasil usahatani kakao.

Pyi : Harga jual hasil usahatani kakao

Untuk menghitung pendapatan digunakan formula (Soekartawi, 1995):

$$
B=T R-T C
$$

Dimana:

B : Pendapatan bersih dari usahatani kakao

TR : Penerimaan dari usahatani kakao

TC : Jumlah biaya produksi dari usahatani kakao

Masalah kedua menyangkut besarnya kontribusi dijawab dengan menggunakan analisis kontribusi usahatani kakao terhadap pendapatan keluarga petani:

$$
K_{K}=\frac{B_{K}}{B_{\text {Total }}} \times 100 \%
$$

Dimana:

$$
\begin{array}{ll}
\mathrm{K}_{\mathrm{k}} & \text { : Kontribusi usahatani kakao } \\
\mathrm{B}_{\mathrm{k}} & \text { : Pendapatan usahatani kakao } \\
\mathrm{B}_{\text {Total }} & \text { : Pendapatan total }
\end{array}
$$

Masalah ketiga menyangkut faktor-faktor apa yang berhubungan dengan tingkat pendapatan rumah tangga petani kakao dijawab dengan menggunakan alat analisis Regresi Linier Berganda. Menurut Wibisono (2005) formula untuk kedua alat analisis adalah :

$$
Y=\alpha+\beta_{1} X_{1}+\beta_{2} X_{2}+\beta_{3} X_{3}+\cdots+\beta_{5} X_{5}+E
$$

Dimana :

Y : Tingkat pendapatan Rumah Tangga Petani dari usahatani Kakao

$\alpha \quad$ : Intercep/konstanta

$\beta_{1} \ldots \beta_{5}:$ Koefisien Regresi (parameter yang ditaksir)

$\mathrm{X}_{1} \quad:$ Umur

$\mathrm{X}_{2} \quad$ : Tingkat pendidikan

$\mathrm{X}_{3}$ : Jumlah beban tanggungan keluarga

$\mathrm{X}_{4} \quad$ : Luas lahan

$\mathrm{X}_{5} \quad$ : Tenaga Kerja

$\mathrm{X}_{6} \quad$ : Biaya Produksi usahatani Kakao

$\mathrm{X}_{7} \quad$ : Produksi

E : Faktor kesalahan (Error term)

Masalah keempat menyangkut dengan kelayakan usahatani kakao dijawab dengan 
menggunakan alat analisis Benefit Cost Ratio (B/C). Menurut Kadariah, dkk, (1987), ialah perbandingan antara jumlah nilai kini total penerimaan dan jumlah nilai kini biaya. Jika B/C $>1$ maka usahatani kakao layak untuk dikembangkan dan jika $\mathrm{B} / \mathrm{C}<1$ maka tidak layak untuk dikembangkan.

$$
B / C=\frac{B}{C}
$$

Dimana :

$$
\begin{array}{ll}
\mathrm{B} / \mathrm{C} & \text { : Benefit Cost Ratio } \\
\mathrm{B} & \text { : Benefit (Pendapatan) } \\
\mathrm{C} & \text { : Cost (Biaya) }
\end{array}
$$

\section{HASIL DAN PEMBAHASAN}

\subsection{Karakteristik Responden}

\subsubsection{Umur}

Umur petani merupakan salah satu faktor yang berkaitan dengan kemampuan petani dalam mengelolah usahataninya. Semakin tua umur petani kemampuan kerja cenderung menurun, yang akhirnya dapat mempengaruhi produksi dan pendapatan petani itu sendiri. Umur produktif tenaga kerja adalah 14 - 64 tahun (Badan Pusat Statistik). Berdasarkan hasil penelitian yang dilakukan terhadap petani responden, umumnya umur yang dimiliki petani berkisar antara 29-62 tahun. Lebih jelasnya mengenai tingkat umur responden berdasarkan usia produktif dan tidak produktif dari tenaga kerja dapat dilihat pada Tabel 4

Tabel 4. Distribusi Responden Menurut Umur Produktif dan Tidak Produktif

\begin{tabular}{cccc}
\hline \multicolumn{2}{c}{$\begin{array}{c}\text { Umur } \\
\text { (Tahun) }\end{array}$} & $\begin{array}{c}\text { Jumlah } \\
\text { ( orang ) }\end{array}$ & $\begin{array}{c}\text { Persentase } \\
\text { ( \% ) }\end{array}$ \\
\hline Produktif & $14-64$ & 32 & 43,75 \\
Non Produktif & $65-84$ & 0 & 56,25 \\
\hline \multicolumn{2}{c}{ Jumlah } & $\mathbf{3 2}$ & $\mathbf{1 0 0}$ \\
\hline
\end{tabular}

Sumber : Data Primer 2010.

Tabel 4. memperlihatkan bahwa petani responden yang ada seluruhnya berada pada umur produktif tenaga kerja yaitu sebanyak 32 responden $(100 \%)$. Sedangkan petani yang berada pada umur non produktif tidak ada atau (0 $\%)$. Petani yang berada pada usia produktif tenaga kerja 14 - 64 tahun biasanya mempunyai semangat kerja yang tinggi dalam menjalankan kegiatan usahataninya, karena ditunjang oleh kemampuan fisik yang masih baik dan sudah mempunyai pengalaman, sehingga masih berpotensi untuk mengembangkan usahatani kakao.

\subsection{Pendidikan}

Kualitas sumber daya manusia disektor pertanian relatif rendah bila dibandingkan dengan sektor lainnya, yang ditandai dengan masih rendahnya tingkat pendidikan meskipun ada kemajuan disektor pertanian tetapi petani yang berpendidikan SD cukup besar jumlahnya.

Hasil penelitian juga menunjukkan bahwa kondisi demikian juga terjadi didaerah penelitian, dimana tingkat pendidikan yang dimiliki petani responden dikategorikan pada pendidikan rendah. Hal ini karena petani yang mengusahakan usahatani kakao dengan tingkat pendidikan SD memiliki persentase yang lebih besar dibandingkan dengan tingkat pendidikan yang lain. Lihat Tabel 5.

Tabel 5. Menunjukkan bahwa sebagian besar petani responden di Desa Latu hanya mampu bersekolah pada jenjang Sekolah Dasar (SD) yaitu sebanyak 18 orang $(56,25 \%)$. Hal ini dapat disebabkan dari berbagai hal, seperti rendahnya tingkat ekonomi keluarga sehingga tidak memungkinkan bagi mereka untuk melanjutkan pendidikan ke jenjang pendidikan berikutnya, dan juga pada saat itu jenjang pendidikan SMP dan SMA belum ada di daerah tersebut sehingga mereka tidak melanjutkan sekolah untuk bersekolah ke tempat lain. Sedangkan petani responden yang berada pada tingkat pendidikan SMP sebanyak 7 orang $(21,875 \%)$, SMA sebanyak 6 orang $(18,75 \%)$, dan Akademik/Perguruan Tinggi hanya 1 orang $(1 \%)$

Tabel 5. Distribusi Responden Menurut Pendidikan

\begin{tabular}{lcc}
\hline $\begin{array}{c}\text { Tingkat } \\
\text { Pendidikan }\end{array}$ & $\begin{array}{c}\text { Jumlah } \\
\text { ( orang) }\end{array}$ & $\begin{array}{c}\text { Persentase } \\
(\mathbf{\%})\end{array}$ \\
\hline SD & 18 & 56,25 \\
SMP & 7 & 21,875 \\
SMA & 6 & 18,75 \\
Akademik/PT & 1 & 1 \\
\hline \multicolumn{1}{c}{ Jumlah } & $\mathbf{3 2}$ & $\mathbf{1 0 0}$ \\
\hline
\end{tabular}

Sumber : Data Primer 2010

Berdasarkan data di atas dapat dikatakan bahwa tingkat pendidkan petani kakao di Desa Latu masih rendah yaitu hanya sebatas bangku SD, sehingga akan berpengaruh terhadap kemampuan para petani untuk meningkatkan ketrampilan dan untuk menyerap informasi dan proses adopsi inovasi. Menurut Mosher (1998), pendidikan formal bertujuan untuk menyiapkan diri para petani dalam menghadapi kehidupan sekarang maupun di masa yang akan dating. Maka untuk mengatasi masalah tersebut para petani perlu 
mendapatkan pendidikan non formal misalnya, melakukan berbagai jenis penyuluhan kepada para petani.

\subsection{Jumlah Tanggungan Keluarga}

Jumlah tanggungan keluarga adalah banyaknya orang yang berada dalam rumah tangga. Berdasarkan hasil penelitian, umumnya keluarga dari petani responden berkisar antara $2-$ 9 orang (Lampiran 1). Lihat Tabel 6.

Tabel 6, memperlihatkan bahwa petani dengan jumlah tanggungan keluarga sedang (4 6 orang) memiliki persentase tertinggi yaitu $68,75 \%$ atau sebanyak 22 responden. Kemudian di ikuti oleh jumlah tanggungan kepala keluarga dengan kategori tinggi (7 - 9 orang) sebesar $21,875 \%$ atau sebanyak 7 responden. Sedangkan jumlah tanggungan kepala keluarga dengan kategori rendah (<3 orang) adalah yang paling terendah yaitu sebesar $9,375 \%$ atau sebanyak 3 responden.

Tabel 6. Distribusi Responden Menurut Jumlah Tanggungan Keluarga

\begin{tabular}{|c|c|c|}
\hline $\begin{array}{l}\text { Jumlah tanggungan } \\
\text { kepala keluarga } \\
\text { (orang) }\end{array}$ & $\begin{array}{l}\text { Jumlah } \\
\text { (orang) }\end{array}$ & $\begin{array}{c}\text { Persentase } \\
(\%)\end{array}$ \\
\hline Rendah $\quad(<3)$ & 3 & 9,375 \\
\hline$(4-6)$ & 22 & 68,75 \\
\hline Tinggi $\quad(7-9)$ & 7 & 21,875 \\
\hline Jumlah & 32 & 100 \\
\hline
\end{tabular}

Sumber : Data Primer 2010

Jumlah tanggungan kepala keluarga dapat dijadikan sebagai faktor pendorong bagi petani untuk bekerja lebih giat dalam mengolah usahataninya untuk memenuhi kebutuhan keluarganya.

Sejalan dengan itu, Hernanto (1996) mengatakan bahwa semakin besar beban tanggungan dalam suatu keluarga maka petani akan lebih giat dengan berusaha dan bekerja dalam kegiatan usahataninya untuk memperoleh pendapatan yang lebih besar sehingga kesejahteraan petani dan seluruh anggota keluarga dapat terpenuhi.

\subsection{Luas Lahan Usaha}

Ketidakmerataan pendapatan rumah tangga di pedesaan yang berbasis pertanian berkaitan erat dengan ketidakmerataan struktur penguasaan lahan pertanian (Nurmanaf, 2001). Sebagian besar rumah tangga petani yang berlahan sempit mengandalkan usahatani sebagai sumber utama pendapatan. Lahan adalah tanah yang digunakan untuk usaha pertanian. Luas penguasaan lahan pertanian merupakan sesuatu yang sangat penting dalam proses usahatani (Daniel, 2002).

Lahan usahatani yang dimiliki petani pada daerah penelitian berkisar antara 0,1 - 3 hektar (Lampiran 1). Tingkat luas usahatani menggambarkan tingkat kesejahteraan petani, semakin luas lahan usahatani menggambarkan semakin tinggi produksi dan pendapatan yang diterima. Pemilikan lahan yang sempit cenderung akan berakibat pada sedikitnya hasil panen yang didapat yang akan berimbas pada pendapatan petani serta kemampuan memenuhi kebutuhan hidup. Dan sebaliknya pemilikan lahan yang luas akan menghasilkan hasil panen yang melimpah yang akan membuat terpenuhinya kebutuhan hidup petani itu sendiri.

Menurut Hernanto (1996) petani dapat dikelompokkan berdasarkan luas lahan usahataninya yaitu :

a. Golongan petani sempit ( $<0,5 \mathrm{Ha})$

b. Golongan petani sedang $(0,5-2 \mathrm{Ha})$

c. Golongan petani luas $(>2 \mathrm{Ha})$

d. Golongan buruh tani tidak bertanah Perbedaan golongan petani berdasarkan luas lahan tersebut akan berpengaruh terhadap sumber dan distribusi pendapatannya. Luas lahan usaha petani kakao pada daerah penelitian dapat dilihat pada Tabel 7.

Tabel 7. Distribusi Petani Responden Menurut Luas Lahan Usaha

\begin{tabular}{lccc}
\hline $\begin{array}{c}\text { Kategori } \\
\text { Lahan }\end{array}$ & $\begin{array}{c}\text { Luas } \\
\text { Lahan } \\
\text { (Ha) }\end{array}$ & $\begin{array}{c}\text { Jumlah } \\
\text { (orang) }\end{array}$ & $\begin{array}{c}\text { Persentase } \\
(\%)\end{array}$ \\
\hline Sempit & $<0,5$ & 6 & 18,75 \\
Sedang & $0,5-2$ & 25 & 78,125 \\
Luas & $>2$ & 1 & 3,125 \\
\hline \multicolumn{2}{c}{ Jumlah } & $\mathbf{3 2}$ & $\mathbf{1 0 0}$ \\
\hline Sumber : Data Primer 2010 & &
\end{tabular}

Hasil penelitian pada Tabel 7. menunjukkan bahwa petani kakao yang berada pada daerah penelitian lebih banyak mengusahakan usahatani kakao pada lahan sedang yaitu sebanyak 25 orang $(78,125$ persen), pada kategori lahan sempit sebanyak 6 orang (18,75 persen), dan pada kategori lahan luas hanya 1 orang $(3,125$ persen).

\subsection{Tenaga Kerja}

Setiap usahatani yang dilakukan pasti memerlukan tenaga kerja yang dapat diperoleh dari dalam keluarga maupun luar keluarga. Hasil penelitian menunjukkan bahwa penggunaan 
tenaga kerja pada usahatani kakao berasal dari dalam keluarga dan juga dari luar keluarga yang dicurahkan untuk setiap kegiatan mulai dari pemeliharaan sampai pada pasca panen.

Berdasarkan hasil penelitian, kegiatan pembibitan dan penanaman umumnya dilakukan sendiri oleh petani responden, hanya satu responden yang menggunakan tenaga kerja dari luar keluarga untuk tahapan kegiatan ini. Untuk pembibitan Rp 200.000 per 5 orang, dan untuk penanaman menggunakan 3 tenaga kerja dengan upah Rp 1.500 per pohon.

Pemeliharaan pohon kakao dilakukan dengan cara pemangkasan dan perampasan buah yang busuk dan rusak akibat terserang hama dan juga pembersihan terhadap gulma yang berada disekitar tanaman induk. Tenaga kerja yang digunakan adalah tenaga kerja dari dalam keluarga dan juga dari luar keluarga. Berdasarkan hasil penelitian hanya sebagian kecil petani yang hanya menggunakan tenaga kerja dari luar keluarga. Untuk kegiatan pemeliharaan, petani yang menggunakan tenaga kerja dari luar keluarga umumnya menyewa buru tani dengan upah $\mathrm{Rp} 100.000$ untuk 3 orang pekerja dalam satu kali kerja. Untuk frekuensi waktu pembersihan dalam satu tahun dengan menggunakan tenaga kerja dari luar keluarga tergantung dari keadaan perkebunan petani. Kegiatan pembersihan biasanya paling banyak dilakukan tiga kali dalam satu tahun.

Kegiatan panen untuk tanaman kakao meliputi pengambilan buah yang masak dan memecahkan buah kemudian mengambil bijinya yang basah. Untuk kegiatan panen, petani selain menggunakan tenaga kerja dari dalam keluarga juga menggunakan tenaga kerja dari luar keluarga. Upah yang diterima dari tenaga kerja luar keluarga untuk kegiatan panen adalah $\mathrm{Rp}$ 50.000 per orang, dengan frekuensi lima sampai tujuh kali dalam musim panen.

Tenaga kerja dalam keluarga umumnya tidak diupah secara langsung, sehingga biaya tunai yang dibayar tidak ada. Sejalan dengan itu, Mubyarto (1994) mengatakan bahwa tenaga kerja yang berasal dari dalam keluarga yang terdiri dari ayah, ibu dan anak merupakan sumbangan keluarga petani pada produksi pertanian secara keseluruhan yang tidak pernah dinilai dengan uang.

\subsection{Biaya Produksi}

Menurut Wasis (1992), biaya produksi ialah pengorbanan-pengorbanan yang mutlak harus diadakan agar dapat diperoleh suatu hasil.
Tanpa biaya pengorbanan-pengorbanan tidak akan dapat diperoleh suatu hasil dan pengorbanan-pengorbanan itu harus diukur dengan nilai uang.

Biaya yang dikeluarkan oleh seorang petani dalam proses produksi serta membawanya menjadi produk disebut biaya produksi yang meliputi biaya tetap dan biaya variabel, biayabiaya yang dikeluarkan dalam proses produksi usahatani kakao tersebut tersaji dalam (Lampiran 5). Lebih jelasnya mengenai biaya produksi pada usahatani kakao dapat dilihat pada Tabel 8 .

Berdasarkan hasil penelitian biaya tetap yang dikeluarkan oleh petani kakao adalah biaya penyusutan peralatan pertanian dan biaya PBB (Pajak Bumi dan Bangunan). Biaya penyusutan peralatan pertanian yang dikeluarkan seperti biaya untuk membeli parang, cangkul, linggis, garpu, penggait, dan arit. Sedangkan biaya variabel meliputi biaya tenaga kerja, biaya pengangkutan, biaya pemasaran dan pembelian benih.

Berdasarkan Tabel 8. biaya penyusutan peralatan pertanian yang dikeluarkan sebesar $\mathrm{Rp}$ 3.274.024,04 dengan rata-rata $\mathrm{Rp} 102.313,25$, biaya PBB (Pajak Bumi dan Bangunan) sebesar Rp 221.000 dengan rata-rata Rp 6.906,25, biaya tenaga kerja sebesar Rp 5.350.000 dengan ratarata $\mathrm{Rp} 167.187,5$, biaya pengangkutan sebesar Rp 740.000 dengan rata-rata Rp 23.125, biaya pemasaran sebesar Rp 770.000 dengan rata-rata Rp 24.062,5 dan untuk biaya benih sebesar Rp 165.000 dengan rata-rata $\mathrm{Rp} 5.156,25$ sehingga total biaya produksi yang dikeluarkan untuk usahatani kakao adalah sebesar Rp 10.520.024,04 dengan rata- rata sebesar $\mathrm{Rp} 328.750,8 /$ tahun. Dimana biaya produksi tertinggi adalah pada upah tenaga kerja dengan persentase sebesar (50,86 persen), hal ini disebabkan karena petani responden tidak hanya saja mengandalkan tenaga kerja dari dalam keluarga tetapi juga mengandalkan tenaga kerja dari luar keluarga atau menyewa orang lain, sehingga harus mengeluarkan biaya untuk memberi upah kerja kepada pekerja atau buru tani.

Kemudian biaya penyusutan peralatan pertanian dengan dengan persentase sebesar 31,12 persen, hal ini disebabkan karena dalam satu tahun frekuensi petani untuk membeli peralatan pertanian adalah 2 sampai 3 kali beli karena cepat rusak dan alat ini tidak saja untuk dipakai pada usahatani kakao tetapi juga digunakan untuk usahatani tanaman lainnya sehingga cepat rusak dan harus menggantinya dengan yang lain. 
Kemudian biaya pemasaran dengan persentase sebesar 7,32 persen. Berdasarkan hasil penelitian petani responden umumnya memasarkan hasil usahatani kakao ke pedagang pengumpul di Desa sehingga tidak memungut biaya. Hanya terdapat 3 responden yang memasarkan hasil pertaniannya ke Ambon atau ibu kota Provinsi, karena harga belinya lebih tinggi bila dibandingkan dengan menjual hasil ke pedagang pengumpul.

Biaya pengangkutan atau transportasi yang dikeluarkan oleh petani responden sebesar 7,04 persen. Berdasarkan hasil penelitian, umumnya petani menggunakan transportasi untuk ke kebun karena di daerah penelitian tersebut terdapat beberapa mobil angkutan (pick up) yang khusus untuk mengangkut masyarakatnya ke lahan pertanian. Biaya yang digunakan untuk mengangkut hasil panen kakao selama 6 sampai 7 kali frekuensi panen dalam satu tahun, biaya angkutan seperti pemeliharaan atau lain-lain tidak diperhitungkan dalam biaya, karena setiap harinya petani pergi ke kebun hanya dengan menggunakan sepeda, sepeda motor atau dengan berjalan kaki.

Di daerah penelitian, petani dalam mengusahakan usahatani kakao tidak pernah menggunakan pupuk, sehingga biaya untuk kegiatan ini tidak ada. Hal ini disebabkan karena petani hanya mengandalkan kondisi alam terhadap tanah dan tanaman yang diusahakan.

Tabel 8. Rata-rata Biaya Produksi Usahatani Kakao

\begin{tabular}{lccc}
\hline \multicolumn{1}{c}{ Biaya Produksi } & $\begin{array}{c}\text { Jumlah Biaya } \\
\text { Produksi (Rp) }\end{array}$ & $\begin{array}{c}\text { Rata-rata Biaya } \\
\text { Produksi (Rp) }\end{array}$ & $\begin{array}{c}\text { Persentase } \\
(\%)\end{array}$ \\
\hline 1. Biaya Tetap : & $3.274 .024,04$ & $102.313,25$ & 31,12 \\
- Penyusutan Alat & 221.000 & $6.906,25$ & 2,1 \\
- PBB & & & \\
2. Biaya Variabel : & 5.350 .000 & $167.187,5$ & 50,86 \\
- Biaya Tenaga Kerja & 740.000 & 23.125 & 7,04 \\
- Biaya Pengangkutan & 770.000 & $24.062,5$ & 7,32 \\
- Pemasaran & 165.000 & $5.156,25$ & 1,56 \\
- Benih & $\mathbf{1 0 . 5 2 0 . 0 2 4 , 0 4}$ & $\mathbf{3 2 8 . 7 5 0 , 8}$ & $\mathbf{1 0 0}$ \\
\hline Total & & &
\end{tabular}

\subsection{Produksi}

Produksi adalah suatu kegiatan dengan mempergunakan berbagai sumber alam untuk menghasilkan barang dan jasa (Hernanto, 1995). Berdasarkan hasil penelitian rata-rata produksi kakao adalah sebesar 405,93 $\mathrm{Kg}$ per tahun dengan rata-rata luas lahan 0,78 ha. Produksi tertinggi yang dimiliki oleh petani responden adalah $850 \mathrm{~kg}$ dan terendah $50 \mathrm{~kg}$ per tahun. Untuk lebih jelasnya mengenai produksi kakao lihat Tabel 9.

Tabel 9. Rata-rata Luas Lahan dan Produksi Kakao

\begin{tabular}{ccc}
\hline $\begin{array}{c}\text { Rata-Rata } \\
\text { Luas Lahan } \\
\text { (Ha) }\end{array}$ & $\begin{array}{c}\text { Total Produksi } \\
(\mathrm{Kg})\end{array}$ & $\begin{array}{c}\text { Rata-Rata } \\
\text { Produksi } \\
(\mathrm{Kg})\end{array}$ \\
\hline 0,78 & 12.990 & 405,93 \\
\hline Sumber : Data Primer 2010 &
\end{tabular}

Semakin luas lahan yang diusahakan, maka semakin banyak jumlah tanaman yang dapat ditanam dan produksi semakin meningkat demikian sebaliknya. Rendahnya produksi yang dihasilkan petani dari usahatani kakao disebabkan oleh luas lahan yang kecil 0,2 ha dan kurangnya pemeliharaan yang intensif serta adanya serangan hama dan penyakit. Faktorfaktor yang menyebabkan adanya perbedaan produksi kakao antara lain jarak tanam dan umur tanaman. Jarak tanaman yang digunakan petani responden sangat verbervariasi antara lain $2.5 \mathrm{~m}$ x $3 \mathrm{~m}, 3 \mathrm{~m}$ x $3 \mathrm{~m}$, dan $4 \mathrm{~m}$ x $4 \mathrm{~m}$. Menurut Sunanto (1992), jarak tanam yang baik untuk tanaman kakao adalah $3 \mathrm{~m} \times 3 \mathrm{~m}$. Hal ini agar tajuk tanaman tidak saling bersentuhan dan tanaman bisa mendapat cahaya sinar matahari yang cukup untuk pertumbuhan dan perkembangan tanaman tersebut.

Tanaman kakao di Desa Latu berumur antara $8-30$ tahun. Umur tersebut menunjukkan keadaan tanaman kakao ada yang masih produktif dan ada yang telah melewati satu siklus hidup tanaman kakao. Menurut Sunanto (1992), siklus hidup tanaman kakao sampai pada umur 25 tahun, jika pemeliharaannya dilakukan secara baik akan terus berproduksi namun produksinya akan menurun. Selain itu banyak tanaman yang terserang oleh hama penggerek buah yaitu Cacao Mot dan penyakit busuk buah atau Botrydiplodia theobramae Pat. 


\subsection{Pendapatan Usahatani Kakao}

Salah satu indikator yang digunakan untuk mengukur tingkat hidup dan kesejahteraan petani adalah tingkat penghasilan yang diterima oleh keluarga petani. Pendapatan adalah selisih antara penerimaan dengan biaya produksi yang digunakan dalam proses produksi.

Tabel 10. Distribusi Responden Menurut Tingkat Pendapatan dari Usahatani Kakao di Desa Latu

\begin{tabular}{lcc}
\hline $\begin{array}{c}\text { Skala Pendapatan } \\
\text { (Rp) }\end{array}$ & $\begin{array}{c}\text { Jumlah } \\
\text { (orang) }\end{array}$ & $\begin{array}{c}\text { Persentase } \\
\text { (\%) }\end{array}$ \\
\hline Rendah & 13 & 40,625 \\
$742.250-5.513 .750$ & & \\
Sedang & 12 & 37,5 \\
$\begin{array}{l}5.550 .000-1.063 .750 \\
\text { Tinggi } \\
>11.100 .000\end{array}$ & 7 & 21,875 \\
\hline \multicolumn{1}{c}{ Total } & $\mathbf{3 2}$ & $\mathbf{1 0 0}$ \\
\hline $\begin{array}{l}\text { Sumber : Data Primer 2010 } \\
\text { Bet }\end{array}$
\end{tabular}

Berdasarkan Table 10. dapat dilihat bahwa sebanyak 13 petani responden (40,625 persen) mempunyai tingkat pendapatan yang rendah, kemudian sebanyak 12 petani responden $(37,5 \%)$ mempunyai tingkat pendapatan yang sedang dan sebanyak 7 petani responden $(21,875 \%)$ yang mempunyai tingkat pendapatan tinggi.

Hasil penelitian menunjukkan bahwa total pendapatan dari usahatani kakao di Desa Latu adalah sebesar Rp 239.620.955 dengan rata-rata pendapatan sebesar Rp 7.488.154,83. Pendapatan petani responden kakao di Desa Latu tertinggi sebesar Rp 16.541.250 dan terendah sebesar Rp 742.250. Tinggi rendahnya pendapatan petani di Desa Latu dipengaruhi oleh besarnya biaya yang dikeluarkan dalam mengusahakan usahatani kakao dan besarnya penerimaan petani yang diperoleh dari hasil penjualan biji kakao. Pendapatan petani juga dipengaruhi oleh luas lahan, tingkat produksi. Selengkapnya mengenai rata-rata penerimaan, biaya produksi dan pendapatan dari usahatani kakao dapat dilihat pada Tabel 11.

Tabel 11. Rata-Rata Penerimaan, Biaya Produksi dan Pendapatan Usahatani Kakao di Desa Latu

\begin{tabular}{lcr}
\hline \multicolumn{1}{c}{ Uraian } & Total & \multicolumn{1}{c}{ Rata-Rata } \\
\hline Penerimaan (Rp) & 249.755 .000 & $7.804 .843,75$ \\
Biaya Produksi (Rp) & $10.520 .024,0$ & $328.750,8$ \\
Pendapatan (Rp) & 239.234 .976 & $7.476 .092,95$ \\
\hline
\end{tabular}

Sumber : Data Primer 2010

Berdasarkan Tabel 11. Dapat dilihat bahwa rata-rata penerimaan dari usahatani kakao per tahun sebesar Rp 7.804.843,75. Rata-rata biaya produksi yang dikeluarkan per tahun sebesar $\mathrm{Rp}$
328.750,8 dan rata-rata pendapatan yang diperoleh per tahun sebesar Rp 7.476.092,95.

Menurut Prayitno (1987), mengatakan bahwa besar kecilnya pendapatan usahatani ditentukan oleh luas lahan garapan dan harga jual yang berlaku. Harga jual yang ditentukan berkisar Rp 17.000 - Rp 20.000/kg/biji kakao kering. Sedangkan luas lahan berkisar antara 0,1 - 3,00 Ha dengan rata-rata jumlah pohon sebanyak 477,5 pohon (Lampiran 1).

Dalam analisa usahatani ini, pendapatan petani digunakan sebagai indikator penting karena merupakan sumber utama dalam mencukupi kebutuhan hidup sehari-hari. Besar kecilnya tingkat pendapatan turut menentukan besar kecilnya tingkat kemiskinan rumah tangga petani. Semakin tinggi tingkat pendapatannya maka cenderung mempengaruhi tingkat kemiskinannya. Tingkat kemiskinan menurut Sajogyo melihat kemiskinan dari segi komsumtif atau kemampuan konsumsi beras pertahun yang kuantitaskan dengan batas garis kemiskinan Rp 220.000 per kapita per bulan.

Secara relatif petani kakao yang berada di desa Latu masih ada yang miskin. Berikut ini tingkat kemiskinan rumah tangga petani kakao di desa Latu menurut indikator Sajogyo yang diukur berdasarkan tingkat pendapatan rumah tangga petani perkapita perbulan.

Tabel 12. Tingkat Kemiskinan Rumah Tangga Petani Kakao di Desa Latu berdasarkan Kriteria Sajogyo

\begin{tabular}{|c|c|c|c|c|}
\hline \multirow{2}{*}{ 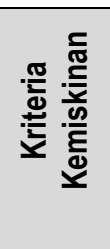 } & \multicolumn{2}{|c|}{$\begin{array}{c}\text { Tingkat } \\
\text { Kemiskinan (\%) } \\
\text { di Desa Latu }\end{array}$} & \multirow{2}{*}{$\begin{array}{c}\text { Total } \\
(\%)\end{array}$} & \multirow{2}{*}{ 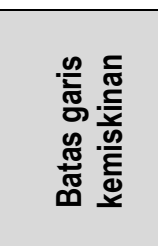 } \\
\hline & $\begin{array}{c}\text { Miskin } \\
(\%)\end{array}$ & $\begin{array}{c}\text { Tdk } \\
\text { Miski } \\
\text { n (\%) }\end{array}$ & & \\
\hline Sajogyo & $\begin{array}{c}78,13 \\
(25)\end{array}$ & $\begin{array}{c}21,87 \\
(7)\end{array}$ & 100 & Rp 220.000 \\
\hline
\end{tabular}

Sumber : Data Primer 2010

Hasil penelitian menunjukan bahwa tingkat kemiskinan rumah tangga petani kakao di Desa Latu mencapai 78,13 persen atau sebanyak 25 responden dari total 32 responden berdasarkan indikator Sajogyo.

Hal ini menunjukan bahwa sebagian besar pendapatan rata-rata per kapita perbulan rumah tangga petani di daerah penelitian masih berada di bawah garis batas kemiskinan berdasarkan indikator Sajogyo.

Dari hasil analisis tersebut terlihat bahwa usahatani kakao belum secara optimal dapat memperbaiki taraf hidup petani. Oleh karena itu perlu dilakukan upaya untuk meningkatkan 
produksi agar kontribusi pendapatan usahatani meningkat. Hal ini sejalan dengan pendapat Gittinger (1986) bahwa untuk meningkatkan pendapatan petani dapat ditempuh dengan melaksanakan upaya peningkatan produksi dan perbaikan kualitas hasil. Dengan demikian tujuan pembangunan nasional di bidang pertanian untuk meningkatkan kesejahteraan petani dapat dicapai melalui perbaikan dan penganekaragaman usahatani.

\subsection{Analisis Regresi Linier Berganda faktor- faktor yang berhubungan dengan Tingkat Pendapatan Rumah Tangga Petani Kakao}

Hubungan antara faktor umur, tingkat pendidikan, jumlah beban tanggungan keluarga, luas lahan, tenaga kerja, dan biaya produksi terhadap pendapatan usahatani kakao berdasarkan analisis Regresi Linier Berganda dapat dilihat pada Tabel 8.

Berdasarkan hasil analisis dengan menggunakan Regresi Linier Berganda, diperoleh persamaan regresi sebagai berikut.

\section{$Y=8899351-65713,0 X_{1}-807304 X_{2}-$ $154446 X_{3}+4703296 X_{4}+195750,1 X_{5}+$ $1,601 X_{6}$}

Dari persamaan di atas maka dapat disebutkan bahwa faktor umur, pendidikan, beban tanggungan keluarga, luas lahan, tenaga kerja dan biaya produksi berpengaruh terhadap tingkat pendapatan usahatani kakao di Desa Latu. Hal ini dapat dipertegas dengan membuktikan nilai $\mathrm{F}$ hitung $>\mathrm{F}$ tabel pada hasil analisis varians. Hasil analisis varians menunjukkan bahwa nilai $\mathrm{F}$ hitung yang diperoleh sebesar 3,725 dan $\mathrm{F}$ tabel sebesar 2,60, sehingga persamaan regresi diatas adalah signifikan. Maka dapat disimpulkan bahwa faktor umur, pendidikan, beban tanggungan keluarga, luas lahan, tenaga kerja dan biaya produksi berpengaruh signifikan (nyata) terhadap tingkat pendapatan usahatani kakao.

Besarnya pengaruh faktor umur, pendidikan, beban tanggungan keluarga, luas lahan, tenaga kerja dan biaya produksi terhadap tingkat pendapatan usahatani kakao dapat dilihat berdasarkan nilai Koefisien Determinasi $\left(\mathrm{r}^{2}\right)$. Nilai koefisien determinasi yang diperoleh adalah sebesar 0,472 berarti penggunaan faktor umur, pendidikan, beban tanggungan keluarga, luas lahan, tenaga kerja, dan biaya produksi yang dimasukkan ke dalam model regresi berpengaruh sebesar 47,2 persen terhadap pendapatan usahatani kakao di Desa Latu, sedangkan sisanya
52,8 persen dipengaruhi oleh faktor lain yang tidak dimasukkan dalam model regresi seperti kesuburan tanah, iklim, dan cuaca.

\subsection{Analisis Kelayakan Usahatani Kakao}

Sistem usahatani kakao adalah bagaimana memadukan faktor-faktor produksi untuk memperoleh suatu hasil dalam usahatani kakao. Usahatani yang baik adalah suatu usahatani yang layak. Layak atau tidak layaknya suatu usahatani dapat dianalisis dengan beberapa formula, misalnya NPV, BCR, IRR, ROI, R/C.

Analisis kelayakan usahatni kakao di daerah penelitian dianalisis dengan metode Benefit Cost Ratio (BCR). Nilai BCR yang diperoleh merupakan perbandingan antara pendapatan yang diperoleh dengan besarnya biaya yang dikeluarkan petani selama proses produksi.

Hasil penelitian pada Tabel 10. Menunjukkan bahwa rata-rata pendapatan yang diperoleh lebih besar dari rata-rata total biaya produksi yang dikeluarkan dan rata-rata nilai BCR adalah sebesar 23,65. Nilai ini menunjukkan bahwa usahatani kakao di Desa Latu layak untuk dikembangkan karena nilai BCR yang diperoleh lebih besar dari 1 . Hal ini berarti bahwa setiap penambahan satu satuan input produksi, maka akan memberikan keuntungan sebesar 23,65 rupiah.

\section{KESIMPULAN DAN SARAN}

\subsection{Kesimpulan}

Berdasarkan hasil penelitian, maka dapat disimpulkan bahwa :

1. Tingkat pendapatan yang diperoleh petani dari hasil usahatani kakao tergolong sedang jika dibandingkan dengan Upah Minimum Regional (UMR) untuk tanaman perkebunan pada Provinsi Maluku yaitu sebesar Rp 840.000 per bulan dengan rata-rata pendapatan petani kakao di Desa Latu per tahun adalah sebesar Rp 7.488.154,83.

2. Usahatani kakao memberikan kontribusi yang sedang yaitu 17,7 persen jika dibandingkan dengan kontribusi dari usahatani lainnya maupun dari sektor non usahatani.

3. Berdasarkan hasil analisis dengan Regresi Linier Berganda, faktor umur, pendidikan, jumlah beban tanggungan keluarga, luas lahan, tenaga kerja, dan biaya produksi mempengaruhi tingkat pendapatan rumah tangga petani kakao sebesar 47,2 persen.

4. Kelayakan usahatani kakao di Desa Latu dilihat dari nilai BCR sebesar 23,65. Nilai ini 
lebih besar dari 1 yang menunjukkan bahwa setiap penambahan satu satuan input produksi akan memberikan penambahan keuntungan usahatani sebesar 23,65 rupiah.

\section{2. $S$ a $r$ a $n$}

1. Kepada Pemerintah daerah untuk mengadakan penyuluhan dan pelatihan agar petani dapat meningkatkan kuantitas dan kualitas kakao.
2. Kepada petani agar lebih memperluas area perkebunan kakao karena kakao memiliki nilai ekonomi yang tinggi sehingga pendapatan meningkat. Dan juga perlu lebih ditingkatkan kegiatan pemeliharaan secara intensif agar pertumbuhan tanaman menjadi lebih baik dan produksi yang diharapkan akan meningkat

\section{DAFTAR PUSTAKA}

Anonymous, 2006. Ekonomi Petani Indonesia. FSPI, Jakarta

Badan Pusat Statistik. 2008.Maluku Dalam Angka. Ambon.

Hernanto. 1996. Ilmu Usahatani. Penerbit PT. Swadaya Jakarta.

Mosher. 1998. Menggerakkan dan Membangun Pertanian, Yasaguna. Jakarta.

Soekartawi. 1995. Analisis Usahatani. Penerbit Universitas Indonesia. Jakarta.

Sunanto. X.F., 1994. Tanaman Kakao. Budidaya dan Pengolahan Hasil. Kanisius, Yogyakarta.

Sunanto, Hatta. 1992. Cokelat Pengolahan Hasil dan Aspek Ekonominya. Kanisius. Yogyakarta.

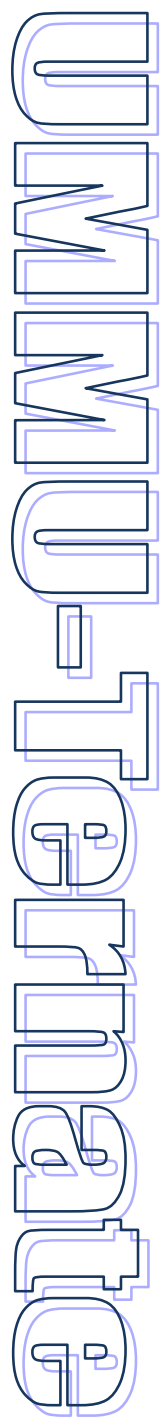

